\title{
Rules, Principles, and the Accounting Crisis in the United States
}

William W. Bratton

Georgetown University Law Center, wwb@law.georgetown.edu

Copyright @ 2004 Cambridge University Press; http://journals.cambridge.org/action/ displayJournal?jid=EBR

This paper can be downloaded free of charge from:

https://scholarship.law.georgetown.edu/facpub/580

http://ssrn.com/abstract $=607361$

5 Eur. Bus. Org. L. Rev. 7-36 (2004)

This open-access article is brought to you by the Georgetown Law Library. Posted with permission of the author. Follow this and additional works at: https://scholarship.law.georgetown.edu/facpub

Part of the Accounting Law Commons, Business Organizations Law Commons, and the Securities Law Commons 


\title{
Rules, Principles, and the Accounting Crisis in the United States
}

\section{William W. Bratton}

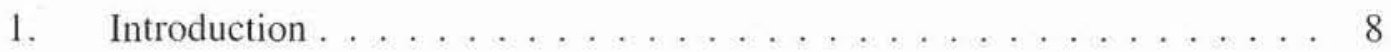

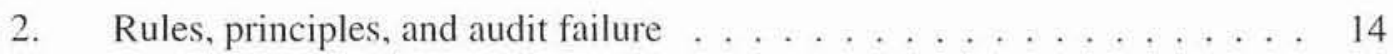

2.1 Standard setting and audit failure . . . . . . . . . . . . . . . . . . . . 14

2.2 Enron and GAAP . . . . . . . . . . . . . . . . . . . . . . . . . 19

2.3 Summary. . . . . . . . . . . . . . . . . . . 23

3. The demand for rules . . . . . . . . . . . . . . . . . . . . 24

3.1 FASB: The responsive standard setter. . . . . . . . . . . . 25

3.2 Audit firm demands . . . . . . . . . . . . . . . . . . . . . . . 28

3.3 The legal profession compared . . . . . . . . . . . . . . . . 29

4. Relative merits of rules and principles: ideal conditions and incentive incompatibility. . . . . . . . . . . . . . . . . . 30

4.1 Cost savings and transparency. . . . . . . . . . . . . 30

4.2 Flexibility and professional judgment . . . . . . . . . . . . . . 32

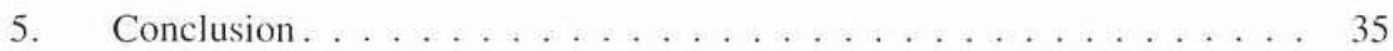

\begin{abstract}
The Sarbanes-Oxley Act and the Securities Exchange Commission move too quickly when they prod the Financial Accounting Standards Board, the standard setter for US GAAP, to move immediately to a principles-based system. Priorities respecting reform of corporate reporting in the US need to be ordered more carefully: Incentive problems impairing audit performance should be solved first through institutional reform insulating the audit from the negative impact of rent-seeking and solving adverse selection problems otherwise affecting audit practice. So long as auditor independence and management incentives respecting accounting treatments remain suspect, the US reporting system holds out no actor plausibly positioned to take responsibility for the delicate law-to-fact applications that are the hallmarks of principles-based systems. Principles, taken alone, do little to constrain rent-seeking
\end{abstract}


behaviour. In a world of captured regulators, they invite applications that suit the regulated actor's interests. Rules, with all their flaws, better constrain managers and compromised auditors. Broadbrush reformulations of rulesbased GAAP should follow only when institutional reforms have succeeded.

Keywords: corporation and securities law, illegal behaviour and the enforcement of law, accounting and auditing general.

\section{INTRODUCTION}

American equityholders awoke in 2002 to realize they no longer could trust corporate financial reports.' Their doubts extended beyond Enron and the Arthur Andersen firm ${ }^{2}$ to a large set of companies with reputations for aggressive accounting. Entire sectors were implicated, finance and telecommunications most prominently. Securities issuers, oriented toward shareholder value enhancement by the corporate culture of the 1990s, had been adopting aggressive, even fraudulent treatments to enhance reported earnings, and their auditors had been doing nothing to stop them. The auditors had sold their independence in exchange for consulting rents. The Securities and Exchange Commission (SEC), some years before, had issued loud warnings about this dirty deal and its implications for reporting quality. But nobody in the investment community paid attention so long as money kept falling from the sky during the 1990s bull market. Things were different in 2002. As equityholders struggled in the worst bear market in a generation, diminished auditor independence triggered a crisis of

' See, e.g., G. Morgenson, 'Worries of More Enrons to Come Give Stock Prices a Pounding', N.Y. Times (30 January 2002) p. C1.

2 For a review of Enron disaster, see W.W. Bratton, 'Enron and the Dark Side of Shareholder Value', 76 Tulane L. Rev. (2002) p. 1275.

${ }^{3}$ See, e.g., A. Levitt, 'Renewing the Covenant With Investors', Speech given at the New York University Center for Law and Business (10 May 2000) (available at <www.sec.gov/news/ speech/spch> (last visited 25 January 2004)). 
confidence in corporate reporting. As audit failures ${ }^{4}$ piled up, investors lost confidence in managers, market intermediaries, and auditors alike. Share prices suffered as a result.

The auditors responded by pointing a finger at US accounting's standardsetter, the Financial Accounting Standards Board (FASB), and the standards it articulates, Generally Accepted Accounting Principles (GAAP). The problem, said the auditors, was a shortage of rules. Auditors and reporting companies needed more guidance and regulators like FASB had failed to supply it. Joe Berardino, the managing partner of the Andersen firm, then under the gun for the audit failure at Enron and subsequent document shredding, led this counterattack. His firm's auditors, he said, had merely applied the rules. It followed that if there was a problem, it lay in the rules themselves, which permitted the off balance sheet financing arrangements that figured prominently in Enron's collapse. If something had gone wrong with the fairness of Enron's financial statements, then the rules ought to be rethought. ${ }^{5}$ The burden to effect improvement lay on the FASB and the SEC rather than on the audit firms: to restore confidence, the SEC should supply 'immediate guidance' to public companies respecting disclosure of off-balance sheet transactions along with other transactional categories where Enron's financials had proved wanting, such as over the counter derivative contracts and related-party transactions. In particular, the SEC should require issuers to provide more details respecting off balance sheet guarantees, commitments, and lease and debt arrangements that variously impact on credit ratings, earnings, cash flow, or stock price."

The decline in compliance has not been limited to companies subject to enforcement actions, such as Cendant: see In re Cendant Corp. Sec. Litig., 109 F. Supp. 2 d 235 (D.N.J. 2000). Investigations and criticisms touch reputable names such as Xerox: see $\mathrm{C}$. Deutsch and $\mathrm{R}$. Abelson, 'Xerox Facing New Pressures Over Auditing', N.Y. Times (9 February 2001) p. Cl; Lucent: S. Romero, 'Lucent's Books Said to Draw Attention of the SEC', N.Y. Times (10 February 2001) p. Cl; American International, Coca Cola, and IBM: see S. Liesman. 'Heard on the Street: Deciphering the Black Box', Wall St. J. (23 January 2002); and General Electric itself. See J. Kahn, 'Accounting in Wonderland: Jeremy Kahn Goes Down the Rabbit Hole with G. E.'s Books', Fortume (19 March 2001) p. 37; R.E. Silverman and K. Brown, 'Five Companies: How They Get Their Numbers', Wall St. J. (23 January 2002) pp. CI. Cl6.

The General Accounting Office Report to the Chairman, Committee on Banking, Housing, and Urban Affairs, U.S. Senate, Financial Restatements: Trends: Market Impacts, Regulatory Responses, and Remaining Challenges (October 2002) (GAO-03-138) [hereafter cited as GAO Report], surveys public company restatements 1997 to 2002, showing marked increases across the period.

J. Berardino, 'Enron: A Wake-Up Call', Wall St. J. (4 December 2001) p. Al8.

" J. Burns and M. Schroeder, 'Accounting Firms Ask SEC for Post-Enron Guide', Wall St. J. (7 January 2002) p. Al6. 
The auditors repeated an oft-heard refrain when they demanded more guidance from the standard setters, and so failed to deflect the blame from themselves. Worse, voices from outside the accounting profession responded to the auditors' defense by singing the opposite tune: Maybe the auditors had too much guidance; maybe the problem was not a shortage of rules on matters like off-balance sheet financing, derivative contracts, and leases, but an excess of rules. The critics charged that GAAP's exhaustive system of rules-based treatments had fostered a dysfunctional, check-the-box approach to compliance. Preparers and auditors applied the rules mechanically, ignoring the substance of the transactions being reported. The rules-based system of regulation, they alleged, fostered a culture of noncompliance in which regulated actors invested in schemes of rule evasion. Harvey Pitt, then the SEC chairman, led the charge against FASB and its rules:

'Present-day accounting standards are cumbersome and offer far too detailed prescriptive requirements for companies and their accountants to follow. We seek to move toward a principles-based set of accounting standards, where mere compliance with technical prescriptions is neither sufficient nor the objective."

Capital Hill staffers, press commentators, and academics seconded Pitt in blaming the crisis on the rules and calling for principles-based accounting.

Even Wall Street joined the call for principles, in a rare moment of concurrence with the policy community. Of course, Wall Street's motivation lay in the association of principles-based accounting with the International Financial Reporting Standards (IFRS) issued by the International Accounting Standards Board (IASB) and selected for adoption by the European Commission. 'The case for principles-based accounting overlaps the case for regulatory intervention to speed international securities market convergence, in particular SEC acceptance of financial reporting pursuant to IFRS. Principles-based accounting thus appeals to every intermediary on Wall Street anticipating more rents from foreign listing business.

S. Liesman, 'SEC Accounting Cop's Warning: Playing By Rules May Not Ward Off Fraud Issues', Wall St. J. (12 February 2002) p. C1; 'Leaders: The Lessons from Enron', Economist (9 February 2002) pp. 9-10.

${ }^{x}$ H.L. Pitt, Testimony Concerning The Corporate and Auditing Accountability, Responsibility, and Transparence Act, Committee on Financial Services, House of Representatives p. 5. Available on the SEC website at <http: www.sec.gov/news/testimony/032002tshlp.htm> (last visited 26 January 2004).

'Effective in 2005, listed companies in the EC will be required to report under IFRS. 
The way thus prepared, the US Congress made its own call for principles when it enacted the Sarbanes-Oxley Act of 2002 (SOA)," the legislation that addresses the reporting crisis and attempts to restore confidence in the securities markets. SOA institutes a new regime of regulation of the accounting profession, following the standard regulatory strategy of delegating the task of filling in the new regime's terms to a new administrative agency, the Public Company Accounting Oversight Board (PCAOB)." On principles-based accounting, in contrast, SOA relies on the old agency, the SEC, ordering it to produce a study of the US accounting system that ascertains the extent to which it is principlesbased (as opposed to rules-based) and reports on the length of time needed to achieve transition to a basis in principles..$^{2}$ The SEC Report, which has appeared in due course, ${ }^{13}$ confirms the relative superiority of principles-based over rules-based accounting and hands to FASB the job of a ground up reconstruction of US GAAP.

1" Sarbanes-Oxley Act of 2002, Pub. Law. 107-204, 116 Stat. 745 (codified in scattered sections of $11,15,18,28$, and 29 U.S.C.).

"Sarbanes-Oxley Act s. 103 (c).

12 Sarbanes-Oxley Act s. 108 (d) provides as follows:

SEC. 108. ACCOUNTING STANDARDS.

(d) STUDY AND REPORT ON ADOPTING PRINCIPLES-BASED ACCOUNTING-

(1) STUDY -

(A) IN GENERAL - The Commission shall conduct a study on the adoption by the United States financial reporting system of a principles-based accounting system.

(B) STUDY TOPICS - The study required by subparagraph (A) shall include an examination of -

(i) the extent to which principles-based accounting and financial reporting exists in the United States;

(ii) the length of time required for change from a rules-based to a principles-based financial reporting system;

(iii) the feasibility of and proposed methods by which a principles- based system may be implemented; and

(iv) a thorough economic analysis of the implementation of a principles-based system.

(2) REPORT - Not later than I year after the date of enactment of this Act, the Commission shall submit a report on the results of the study required hy paragraph (1) to the Committee on Banking. Housing, and Urban Affairs of the Senate and the Committee on Financial Services of the House of Representatives.

S. 108(d) is coupled with s. 108(a), which requires FASB and any other approved standardssetting body to adopt procedures assuring prompt consideration of new rules reflecting 'international convergence on high quality accounting standards.'

1. Office of the Chief Accountant, Office of Economic Analysis, SEC, Study Pursuant to Section 108(d) of the Sarbanes Oxley Act of 2002 on the Adoption by the United States Financial Reporting System of a Principles-Based Accouting System (July 2003), available at <http:// www.sec.gov/news/studies/principlebasedstand.htm> [hereafter cited as SEC Report] (last visited 26 January 2004). 
This Article enters a dissenting opinion. The dissent does not follow from a theoretical preference for rules over principles, however. In theory there need be nothing objectionable in an initiative that privileges principles over rules in the articulation of accounting standards (or, for that matter, any other regulation). Principles, or in lawyer's parlance 'standards', lead to more responsive and flexible regulation. The lawmaker announces a broad-brush directive in the expectation that more particular instructions will derive from law to fact applications over time. Because the principle guides each application to fact, principlesbased standards allow regulators to stay in closer touch with ultimate regulatory objectives even as they allow for variations in the facts of the cases. In contrast, rules-based systems tend toward formalism, even as they also tend to include statements of overarching principles. Whatever their motivating principles, exhaustively articulated rules that treat, categorize and distinguish complex transactions invite mechanical application. In practice, the statement of the rule can come to dominate both the wider regulatory purpose and the particulars of the given case. Problems result, since no system of rules ever can anticipate all future cases. Clever planners exploit the pattern of mechanical application, devising transactions that fit the pattern but evade the regulation's spirit. US GAAP is justifiably famous for reliance on such rule-based treatments.

In the abstract, then, well-drafted principles may offer a better mode for articulating accounting standards. Unfortunately, the US reporting system's infirmities cannot be cured in the abstract. GAAP's rule-based treatments and the proposed move to principles must be evaluated in the process context in which preparers and auditors apply accounting principles. The process picture is not pretty. Professional standards have fallen to such a low estate that a near term shift to a principles-based system would create a significant risk of unintended adverse consequences.

Management decides on accounting treatments and prepares financial reports. Auditors merely review these decisions. ${ }^{14}$ It follows in theory that auditors should be the most independent and adversary of professionals, ready at all times to reject management's treatments as unfair or noncompliant. Unfortunately, in US practice, corporate clients have captured the loyalty of their auditors to a degree comparable to their capture of the loyalty of their lawyers. Multiple factors contribute to this compromise of the professional relationship. Prime among them are nonaudit consulting rents, employment

it The leading discussion of the resulting incentive problem in the legal literature is M.A. Eisenberg, 'Legal Models of Management Structure in the Modern Corporation: Officers, Directors and Accountants', 63 Cal. L. Rev. (1975) p. 375. Eisenberg's critique continues to resonate in 2004. 
opportunities at clients, and audit industry concentration. ${ }^{15}$ Now, had the Congress enacting SOA been serious about realigning auditor incentives and ameliorating their capture by the client interest, the statute would have prohibited all nonaudit forms of business consulting by audit firms. SOA, more cautiously, opts for gradual improvement through periodic professional review. It facilitates audit reform without assuring it, leaving it to the PCAOB and the SEC to address (or finesse) the problem of industry capture.

So long as management incentives respecting accounting treatments and auditor independence remain suspect, the US reporting system holds out no actor plausibly positioned to take responsibility for the delicate law to fact applications that are the hallmarks of principles-based systems. Principles, taken alone, do little to constrain rent-seeking behaviour. In a world of captured regulators, they invite applications that suit the regulated actor's interests. Rules, with all their flaws, better constrain managers and their compromised auditors.

Principles-based accounting may work well in other corporate governance systems or in the US system at some future time. But Congress and the SEC move too quickly in prodding FASB to move immediately to principles-based GAAP. Priorities here need to be ordered with more care. The incentive problems should be solved first through institutional reform that insulates the audit from the negative impact of rent-seeking and solves the adverse selection problems that otherwise impair performance of the audit function in the US. SOA, with its blank check agency delegation, merely starts the reform process. It does not take the concomitant and necessary step of reasserting professional standards. Broadbrush reformulations of rules-based GAAP should follow only when institutional reforms have succeeded.

This Article's subsequent sections proceed as follows. Section 2 traverses the US reporting crisis, situating the rules versus principles debate in the context of recent audit failures. The discussion shows that the wave of audit failures implicates principles-based GAAP much more than it implicates rulesbased GAAP. A story about Enron much in circulation also is falsified. According to the story, Enron exemplities the abuses of rules-based accounting under GAAP and demonstrates the need to move to principles. In reality, Enron violated whatever accounting standards got in its way, whether structured as rules or principles. Responsibility for the disaster does not lie at the door of the drafters of GAAP but at the door of those responsible for implementation and enforcement, Enron's managers and auditors. Section 3 explains why GAAP, which in fact is founded on principles, has evolved towards articulation in rules. The responsibility lies less with FASB, which has been operating as a

${ }^{15}$ The effects of industry concentration are a matter of debate. For the view that intense price competition among audit firms has contributed to low audit quality, see text accompanying n. 65 infira. 
responsive regulator, than with its constituents. The constituents, the preparers and auditors of financial statements, demand rules. Adverse selection problems in their professional relationships motivate the demands. Section 4 compares rules and principles in the second-best world of US audit practice. Rules hold out cost savings and can enhance transparency. Principles make things simpler and enhance the comparability of financial statements across different firms. The problem is that principles presuppose an independent auditor who holds unmitigated professional power over the client and its treatment choices. In the absence of such an actor, the case for a principles-based regime rests on a false premise and holds out risks for audit quality. Section 5 concludes.

\section{RULES, PRINCIPLES, AND AUDIT FAILURE}

Proponents of principles-based accounting blame audit failures and reporting defalcations at firms like Enron and WorldCom on rules-based accounting and look to principles-based reformulations as a corrective tool. The rules, they say, are manipulated by managers, auditors, and consultants toward the end of reporting misstatement. A principles-based system, such as presently in effect in the United Kingdom and in IFRS, would be less manipulable and thus superior. No one challenges these assertions. But, as the discussion that follows shows, the charges are in significant part unfounded. This is not because GAAP contains no manipulable rules, for it does. Nor is this because the rules have not been manipulated, for they have been. It is because recent corporate scandals for the most part do not stem from rule manipulation. There is no persuasive causal connection between rule-based GAAP and recent, catastrophic audit failures. Enron, thought to be the prime case where corporate failure can be tied to rule exploitation, turns out to be much more a case of human pathology than of poor standard setting.

\subsection{Standard setting and audit failure}

According to the SEC's report under SOA on principles-based accounting, rules-based standards are characterized by 'bright line tests, multiple exceptions, a high level of detail, and internal inconsistencies.' A rules-based approach, moreover, seeks to supply a clear answer to every possible situation, thereby minimizing the need to apply professional judgment. ${ }^{16}$ According to GAAP's critics, this leads to transaction structuring and other strategic

"SEC Report, op. cit. n. 13, s. I.C. 
behaviour that undermines the quality of financial reporting. ${ }^{17}$ Financials thus manipulated, while rule compliant, do not truly and fairly state the reporting company's income and financial position. Comparability suffers as a result: Reporting entities hewing to the same strict standard appear comparable on faces of their financials when their arrangements in fact are dissimilar. ${ }^{\text {Is }}$ Principles, say the critics, avoid this reporting pathology and lead to higher quality reporting; an effective system of accounting standards must build on principles and cannot be constructed entirely of rules.

The critics are right that effective accounting standards must have a basis in principles. Unfortunately for the line of criticism. however, GAAP exemplifies just such a system. GAAP is not comprised solely of rules, although some of its directives are indeed set out in elaborately stated rules replete with bright-line tests, multiple exceptions, and internal inconsistencics. Many GAAP standards are principles-based. Furthermore, a collection of hroad and powerful principles stands behind the whole." FASB, upon its inception in 1973, articulated

K. Schipper, 'Principles-Based Accounting Standards', 17 Accounting Horizons (2003) p. 61.

IN. Ibid..p. 67.

"These are, according to a leading legal accounting text. historical cost, objectivity (or verifiability), revenue recognition. matching. consistency, full disclosure, and relevance (or fair value). D.R. Herwitz and M.J. Barrett, Accounting for Lavyers: Materials, $3^{\text {nt }}$ edn. (New York, Foundation 2002) pp. 67-70. The last principle on the list, fair value, lately has been growing in importance at the expense of the first two on the list. historical cost and verifiability. See generally Financial Accounting Standards Board, Preliminary Views on Major Issues Related to Reporting Financial Instruments and Certain Related Assets and Liabilities at Fair Value (1999): S. Siegel. 'The Coming Revolution in Accounting: The Emergence of Fair Value as the Fundamental Principle of GAAP', 42 Wayne L. Rev. (1996) p. 1839. Tension results - there is no way to have a system requiring verifiable numbers and at the same time offering fair value figures. That tension is being resolved in favour of fair value as GAAP moves away liom a mandate that all reported numbers be hard numbers toward a system including many numbers that result from judgment calls but that in theory offer a better picture of the present value of the firm. Note that SOA s. 108(a) directs FASB to prioritize the consideration of new rules reflecting 'emerging accounting principles and changing business practices.' This presumably means more movement to fair value treatments. The Congress overlooks the fact that the same movement certainly played a role in the accounting mess at Enron, where mark to market and fair value accounting of its derivative and energy contracts contributed mightily 10 suspicions about its earnings figures. See F. Partnoy, Testimony Before the Senate Committe'e on Governmental Affecirs (SSRN working paper |IA Revisionist View of Enron and the Sudden Death of "May". available at <http://papers.ssrn.com/sol3/papers.cfm?abstract_id=417261> (last visited 26 January 2004) Il. Common sense indicates that we should readjust the balance in favour of verifiability. at least until the crisis has passed.

Other tensions come into the picture when we relerence two modifying conventions-materiality, which lets the auditor disregard minor misapplications of the rules, and conservatism. which counsels understatement in case of doubt. Between historical cost. verifiability, and conservatism on the one hand, and fair value and materiality on the other, there is much room for good faith dispute about the best way to state a firm's results. 
GAAP's basic principles in a series of Concepts Statements, ${ }^{20}$ collectively called the conceptual framework. This has ever since been the source of the objectives and concepts drawn on in the development of US accounting standards. ${ }^{21}$ The overarching concept in the conceptual framework is 'decision usefulness'. It is in turn supported by the trio of relevance, reliability, and comparability. ${ }^{22}$ Decision usefulness is achieved in the first instance through comparability. That is, similar transactions and conditions should be reported the same way by different firms and by each firm across time. The achievement of comparability in turn necessitates standard setting. Relevance and reliability come into the framework at this point to assist the standard setter in articulating requirements for recognition of income, measurement of assets and liabilities, and disclosure more generally. ${ }^{23}$ As articulated within the conceptual framework, GAAP is explicitly principles-based, even as it contains many rules.

A critic might respond that other accounting systems manage to do as good a job as does US GAAP with materially greater reliance on principles than on rules. The UK regime often is held out at this point. As to auditing standards, the UK system does appear to be more principles-based than those in the US. ${ }^{24}$ But the picture is less clear with respect to the UK's substantive accounting principles. British accounting rests on eight Financial Reporting Standards, twentyfive Statements of Standard Accounting Practice, plus a thick supplementary literature. Much of this is as dense and rule-bound as US GAAP. ${ }^{25}$ The same is true of IFRS. ${ }^{26}$ One commentator, reviewing a number of systems for relative rule-based complexity, including those of the US, the UK and IFRS, found no obvious reason to distinguish US GAAP as a pathological outlier. ${ }^{27}$ All accounting systems mix rules and principles.

More importantly, there is no clear causal connection between rules-based US GAAP and recent high-profile reporting failures. Those who denounce GAAP for excessive reliance on rules cite a number of subject matters. These

20 For FASB's discussion of these in the context of the principles based accounting movement of 2002, see FASB, Principles-Based Approach to U.S. Standard Setting, No. 1125-001 (21 October 2002) pp. 5-7 [hereafter cited as FASB, Principles Approach].

${ }_{21}^{2}$ See FASB, Statement of Financial Accounting Concepts No. 1, Objective of Financial Reporting by Business Enterprises (November 1978).

22 See FASB, Statement of Financial Accounting Concepts No. 2, Qualitative Characteristics of Accounting Information (1980).

${ }^{23}$ Schipper, loc. cit. n 17, pp. 62-63.

${ }^{24}$ See C.A. Frost and K.P. Ramin, 'International Accounting Differences', 181 J. Acct. (1996) p. 62.

${ }^{25}$ L.W. Cunningham, 'The Sarbanes-Oxley Yawn: Heavy Rhetoric, Light Reform (And It Just Might Work)', 35 Conn. L. Rev. (2003) pp. 915, 975-76.

2h See SEC Report, op. cit n. 13, s. I.F.

${ }^{27}$ Cunningham, loc. cit. n. 25, p. 976 n. 291. 
core, rules-based regimes include accounting for derivatives and hedging activity, leasing, real estate sales, stock-based compensation arrangements, consolidation (or other recognition) of related entity financial assets and liabilities, and, prior to reforms instituted in $2002,{ }^{28}$ mergers and acquisitions. ${ }^{20}$ The General Accounting Office's (GAO) recent report of public company accounting restatements permits us to gauge the extent to which these rulesbased subject matter figures into the spate of accounting failures. Since accounting restatements presuppose audit failure, the GAO's compendium provides a roadmap to accounting's abused territories.

The GAO report shows that the annual number of restatements rose from 92 in 1997 to 225 in 2001. From 1997 to June 2002, the total number of restatements announced was $919 .^{30}$ These involved 84.5 companies, amounting ten per cent of all those listed on public exchanges in the US. Issues involving revenue recognition, whether in respect of misreported or nonreported revenue, made up the largest group by subject matter category, accounting for almost 38 per cent of the 919 restatements." The second largest group concerned cost or expenserelated issues, accounting for almost 16 per cent." The GAAP revenue and cost recognition standards bearing on this 54 per cent majority group are for the most part principles-based - they are phrased in general terms and require significant exercises of judgment in their application. "WorldCom is the most famous recent case of these principles" opportunistic misuse. Over three years WorldCom shifted around $\$ 8$ billion of line costs over to asset accounts, treating operating expenditures as capital expenditures, with earnings for the period of the shift increasing dollar for dollar. This age-old ruse for padding earnings implicated neither high-tech engineering nor manipulation of complex rules. ${ }^{3+}$ It was a bad faith application of a principle.

The remaining restatements cover a range of subject matter, some of it rulesbased, but most of it principles-based. On the rules-based side are restatements

2. See FASB, Statement of Financial Accounting Standards No, 141, Business Combinations (June 2001) (ending pooling treatment for mergers).

3.) SEC Report, op. cit. n. 13, ss. I.G, II.B.

6AO Report, op. cit. n 4.

3) Ibid.

:2 Ibid. These types of restatements include instances of improper cost recognition, tax issues, and other cost-related improprieties that led to financial misstatements.

Herwitz \& Barrett, op. cit. n. 19, pp. 449-462, 474-482. The general principles are supplemented by industry specific rules. The door for this supplementation is opened by FASB Concepts Statement No. 5, which bases the revenue recognition standards on the closing practices of its time. But it provides little further conceptual basis. FASB has a current project that looks toward a conceptual restatement. See Schipper, loc. cit. n 17, p. 63.

${ }^{4}$ For description of this fraud, see Cunningham, op. cit. n. 25, pp. 934-36. 
concerning merger and acquisition accounting and derivatives. ${ }^{35}$ More on the principles-based side lie restatements involving in-process research and development, related-party transactions, loan-loss reserves and loan write-offs, asset impairment, inventory valuation, and restructuring activity. ${ }^{36}$

There is a simple reason why rules-based subject matters do not dominate the list of restatements: Detailed rules hold out roadmaps both to GAAP compliance and the identification of GAAP noncompliance. Observers who disapprove of the rules-based treatments ${ }^{37}$ dislike the reporting destinations to which the roadmaps lead. Since these destinations tend simultaneously to be favoured by the managers of reporting companies, the managers happily comply with the rules. At the same time, a noncomplying issuer is more likely to confront an uncooperative auditor. Detailed rules hold out the benefit of enhancing transparency even as they can distort the overall story told by the report's bottom line. They make it easier to see what companies are doing, if only for the reason that the precise instructions narrow the room for differences of judgment. ${ }^{38}$ Rules also ease verification. Detailed instructions provide a base of common assumptions and knowledge for both preparers and auditors. Differences in measurement decrease as a result. Noncompliance becomes more evident. ${ }^{30}$ And the auditor who discovers noncompliance is more likely to refuse to let it pass given a rule. The rule provides it a clear-cut basis for justifying the refusal to the client, minimizing potential damage to the professional relationship. Since the rule makes noncompliance more visible, it also increases the risk of ex post enforcement respecting the preparer and the auditor both, further strengthening the auditor's resolve.

${ }^{35}$ GAO Report, loc. cit. n. 4. Derivatives are a growth item on the list of restatements. Along with other securities-related restatements, they increased from 4.6 per cent of restatements in 2001 to 12.4 per cent of restatements in the first half of 2002. But the category is capacious, and includes errors and misstatements involving derivatives, warrants, stock options, and other convertible securities. Some of the standards in question are rules-based, while others are standards-based. Significantly, most involve fair value accounting.

3. Ibid.

${ }^{37}$ See M.W. Nelson, J.A. Elliott, and R.L. Tarpley, 'Where Do Companies Attempt Earnings Management, and When Do Auditors Prevent It?' This working paper is available at <http:// papers.ssrn.com/sol3/papers.cfm?abstract_id=248129> (last visited 26 January 2004) (showing that auditors pass on these treatments as GAAP compliant).

${ }^{38}$ As noted above, to the extent the rule strategic transaction design, comparability may be lost as dissimilar transactions receive common treatment. Schipper, loc. cit. n. 17, pp. 67-68.

${ }^{39}$ See ibid., p. 68. 


\subsection{Enron and GAAP}

Those who ascribe rules-based standards with a causal role in the accounting crisis point to Enron. At first glance the citation appears justified. Misleading accounting treatments of transactions between Enron and off-balance sheet entities lie at the scandal's core, and the applicable accounting standards are rules-based. Indeed, these rules' form over substance treatments are as notoriously arbitrary as any in US GAAP.

Criticism of these rules has been widespread for decades. Even FASB consistently has joined the critics. For two decades prior to 2001 it kept open a project inquiring into an alternative approach built on a principles-based definition of control. ${ }^{\text {t1 }}$ Unfortunately for FASB, the business community, particularly the securitization industry, had come to rely on its mastery and manipulation of these rules, especially the labyrinthine set on transfers to off-balance sheet entities. The industry interests vociferously opposed reform. Exhausted by the opposition, FASB abandoned the project of substantive restatement as a failure even as the Enron scandal was breaking. Later, in the wake of the scandal, FASB's critics did an about face, suddenly demanding principles-based reform. FASB responded by reviving the reform project, and has since produced a succession of Enron-responsive exposure drafts." FASB's revived reform project amounts to a tacit admission of standard setting failure. For all that appears, even the body responsible for GAAP agrees that its rules had a causative role in the company's collapse.

In acting out the role of a deficient lawmaker, FASB confirms the conventional wisdom circulating in the wake of Enron's collapse. This story follows from the assumption that a disaster of this magnitude never could have occurred had there not been a flaw in the rules. The story has it that Enron exploited technical rules governing Special Purpose Entities (SPE) in setting up and accounting for sham transactions. By carefully but cynically hewing to the rules, Enron managed materially to overstate its earnings. Had the rules been

better drafted, Enron would have been forced to consolidate the results of the

See FASB, Consolidated Financial Statements: Purpose and Policy (proposed 23 February 1999).

"FASB, Consolidation of Certain Special Purpose Entities - an Interpretation of ARB No. $5 /$ (proposed 1 July 2002). This draft deals with SPEs and would have caused the consolidation of Enron's LJM 1 and 2. It also increases the outside equity requirement to ten per cent for a residual class of SPEs that would have included those in question. A second initiative addresses disclosures of guarantees, on the purport that the present rules lack clarity. FASB, Interpretation No. 45, Guarantor's Accounting Disclosure Requirements for Guarantees, Including Indirect Guarantees of Indebtedness of Others (25 November 2002). 
sham SPEs with its own results. Consolidation in turn would have deprived Enron of the opportunity to misstate its earnings. ${ }^{+2}$

Generalizing from the story, rules-based GAAP's layers of precise instructions easily can be manipulated by clever and expensive accountants and lawyers. Had GAAP taken a principles-based approach, articulating general and substantive standards respecting the consolidation of related entities, there would have been no loophole through which the bad actors at Enron could have driven their fleet of sham SPE trucks.

The story is accurate in one respect: the rules respecting accounting for transactions with SPEs were badly drafted and incomplete. But in all other respects the story is nonsense. Enron, in fact, did not follow the rules. Had it done so, the substance of all of its questionable dealings with SPEs would have been disclosed in its financial statements. It follows that the rules did not fail. The failure lay with actors at Enron and its auditor, Arthur Anderson. Failures at FASB played no role. FASB's implicit, after the fact, admission of a rule failure tells us more about its weakness as a political player than it does about the operation of GAAP. . $^{43}$

It is true that the SPE transactions at the heart of the Enron scandal emerged from an exhaustive and strategic planning process. It also is true that the transactions were designed to comply with the rules even as they exploited the rules' structural weaknesses. Under SFAS No. 140, issued in 2000, transfers of financial assets to SPEs are treated as sales by the transferor firm so long as, among other things, equity interests in the SPE are not returned as consideration for the assets transferred and the SPE gets control of the assets with the right to pledge or exchange them. ${ }^{+4}$ For the class of SPEs utilized in the Enron transactions, all the planner had to do was make sure that an outside equity investor in the SPE vehicle contributed capital at least equal to three per cent of the value of the financial assets transferred to the SPE vehicle by Enron.

It also is true that at the time Enron set up the critical 'LJM I' and 'LJM II' SPEs and entered into swap transactions with them, the transactions arguably

\footnotetext{
42 One finds this story casually mentioned as accepted wisdom in the pages of the New York Times at the end of 2002. See K. Eichenwald, 'A Higher Standard for Corporate Advice', N.Y. Times (23 December 2002) pp. A1, A 20 (quoting Professor Frank Partnoy as follows: 'Enron was following the letter of the law in nearly all of its deals. It is fair to say that the most serious allegations of criminal wrongdoing at Enron had almost nothing to do with the company's collapse. Instead it was the type of transaction that is still legal.').

Significantly, reporting companies and the big accounting firms (notably including Andersen and Enron, see G.R. Simpson, 'Deals That Took Enron Under Had Many Supporters', Wall St. J. (10 April 2002) pp. Al, A 13), vigorously opposed FASB's consolidation project, criticizing the FASB's draft as unworkable. S. Burkholder, 'Accounting: Outlook 2002', 34 Sec. Reg. if I. Rip. (2002) pp. 214, 215.

1:ASB. Summary of Statement No. 140, Accounting for Transfers and Servicing of limum iul Assets and Extinguishments of Liabilities (September 2000).
} 
complied with the rules. But, as subsequent investigations have detailed at length, the transaction structures had intrinsic flaws and went out of compliance with the three per cent rule very soon after the transactions closed. ${ }^{+5}$ Had Enron scrupulously followed the rules at that point, it would have been forced to consolidate the SPEs into its financials. Had the SPEs been consolidated, the outcomes of the swap transactions between Enron and the SPEs would have been eliminated from Enron's income statement with the result that Enron would not have been able to pump up its net earnings with revenues and gains from SPE transactions. But, of course, the financials were not consolidated and Enron overstated its earnings by $\$ 1$ billion over five quarters. But the noncompliance did not result from the successful manipulation of flawed rules. Instead, like Parmalat's managers on the other side of the Atlantic, Enron's managers resorted to the old fashioned expedient of concealment.

Enron's financials would have been out of compliance with GAAP even if the financials' treatment of its swaps with LJM had conformed to the rules on consolidation of financials. Consolidation was not the only compliance problem implicated by the LJM transaction structure. Under SFAS No. 57, contracts between Enron and the LJM SPEs were 'related party transactions'. This category includes transactions with a counterparty whose policies are so influenced by the first party as to prevent one of the parties from fully pursuing its own interests. Given such a tie, special footnote descriptions of the transactions are required, including dollar amount impacts on reported earnings. "The footnote disclosures would have provided investors with the substantive equivalent of a set of consolidated reports. But, of course, Enron did not wish to make clear the truth respecting this component of its reported earnings, and its cooperative auditor failed to insist that it follow the rules on related party transactions.

An additional reporting failure figured prominently in Enron's final collapse. The straw that broke the camel's back, frustrated a last-ditch rescue plan, and forced the company to file for bankruptcy in December 2001 was Enron's the last minute revelation of $\$ 4$ billion of unreported centingent guarantees of obligations of unconsolidated equity affiliates. The revelation killed a bailout merger with Dynegy because the hidden $\$ 4$ billion of obligations materially impaired Enron's financial condition and were about to come due. ${ }^{+7}$ As to these obligations GAAP holds out a clear instruction. To guarantee an equity affiliate's obligations is to take the disclosure treatment out of the parentsubsidiary or parent-investee context for treatment under the standards on

${ }^{15}$ W.C. Powers, Jr.. et al., 'Report of Investigation by the Special Investigative Committee of the Board of Directors of Enron Corp.' available at 20()2 WL 198018 (2002) p. 98.

FASB, Statement No. 57, Related Party Disclosures, paras. 2. 24(f) (March 1982).

Bratton. loc. cit. n. 2, pp. 1320-1325. 
contingent losses. Those standards call for disclosure. Under SFAS No. 5, loss contingencies are divided into three classes: probable, reasonably possible, and remote. Probable losses should be accrued as liabilities; reasonably possible losses should be disclosed in footnotes with information as to nature and magnitude; remote losses need not be disclosed. There is a separate rule for financial guarantees such as Enron's. With guarantees, even if the possibility of loss is remote, there must be footnote disclosure as to nature and amount. ${ }^{\text {t\$ }}$ Enron failed to make those disclosures because it was afraid that disclosure could trigger a rating agency downgrade to below investment grade status. (Enron needed an investment grade rating to run its trading business and did everything it could to maintain one). This included material understatement of its obligations as guarantor. This amounts to another old-fashioned fraud by concealment. It comes as no surprise that, thus stated, Enron's financials did not comply with GAAP."

Contrary to the conventional wisdom, then, the central problem at Enron lay not with the rules themselves but with the company's failure to follow them. The Enron disaster stemmed not from the rules' structural shortcomings but from the corruption of Enron's managers and perverse financial incentives that inclined its auditor towards cooperation.

The conventional wisdom errs in a second respect as well. The story blames the complex rules on accounting for SPE transactions. It asserts that had FASB adopted a principles-based approach to consolidation of related entity financial statements, Enron would have been disabled from perpetrating its fraud. Unfortunately for the story, the complex rules governing SPEs in SFAS No. 140 applied in full only to mainstream transactions, like the securitization of pools of mortgages. Enron's SPE transactions did not flow in the mainstream governed by SFAS No. 140. They instead fell into a category of 'other' SPE

See FASB, Statement of Financial Accounting Standards No. 5, Accounting for Contingencies (March 1975) para. 5: 'The Board concludes that disclosure of [guarantees of indebtedness of others and others that in substance have the same characteristic] shall be continued. The disclosure shall include the nature and amount of the guarantee.' See also FASB, Interpretation No. 34, Disclosure of Indirect Guarantees of Indebtedness of Others (March 1981); Herwitz \& Barrett, op. cit. n. 19, pp. 617-20. Note that under SFAS No. 140, a separate recourse obligation against the transferor of an asset to an SPE in respect of reimbursement for losses on the underlying portfolio (as opposed to a derivative arrangement) continues to be treated under SFAS No. 5. That is, the transferor makes an ongoing assessment of the amount of the loss in its financials rather than adjusting the obligation to fair value and reporting it in income. Ernst \& Young, Financial Reporting Developments; Accounting for Transfers and Servicing of Financial Assets and Extinguishments of Liabilities - FASB Statement 140 (May 2001) p. 29.

${ }^{49}$ And therefore were per se misleading for securities law purposes. See 'Administrative Policy on Financial Statements, Accounting Series Rel. No. 4', 11 Fed. Reg. 10,913 (S.E.C. 1938), codified in 'Codification of Financial Reporting Policies, s. 101', reprinted in $7 \mathrm{CCH} \mathrm{Fed.}$ Sec. L. Rep. para. 72,921 (18 May 1988). 
transactions not covered in their entirety by FASB standard-setting. For transactions in the residual category, the critical requirement was a minimum outside equity investment. As to this the accounting firms used a three per cent rule of thumb, derived from a 1991 letter of the Chief Accountant of the SEC issued in respect of a lease transaction. ${ }^{50}$ To read the 1991 letter is to see that the SEC required three per cent outside equity funding on the facts of the leasing case presented to it. The agency never intended to set three per cent as a one-sizefits-all, bright line test. During the 1990 s, the SEC repeatedly pointed out to the accounting profession that no three per cent bright line test existed and that the level of outside equity funding for a qualifying SPE in the residual category should follow from the nature of the transaction. In the SEC's view, the question was whether, on the facts of the case, sufficient outside equity capital had been invested to assure the SPEs independence. ${ }^{5 i}$ The outside equity requirement was thus intended not as a rule but as a flexible principle to be applied in the circumstances. But, despitc the agency's jawboning, the accounting profession applied the principle as a three per cent bright line rule. That rule-based three per cent was the operative assumption when Enron planned the LJM transactions.

A disturbing pattern of communicative breakdown and noncompliance emerges. A standard-setting agency articulates a principle and tells US auditors to apply it as such. The auditors instead bowdlerize the standard so that it operates as a check-the-box rule. At the level of practice, then, US auditors manufacture rules where rules do not exist. A number of questions follow. Why do US auditors display a refractory preference for rules? What prevents auditors from applying standards as intended? Will the behaviour pattern persist under the new principles-based regime projected by GAAP reformers? Responses to these questions follow in sections 3 and 4.

\subsection{Summary}

GAAP's form and content do need improvement and take some of the blame for the US accounting crisis. There can be no denying that practitioners often take advantage of GAAP's rule structures when they design aggressive treatments. Regulatory arbitrage - the practice of structuring an inappropriate transaction

" The GAAP authorities are EITF Topic D-14, 'Transactions involving Special Purpose Intities', EITF 90-15, 'Impact of Nonsubstantive Lessors, Residual Value Guarantees and Other Provisions in Leasing Transactions', and EITF 96-21, 'Implementation Issues in Accounting for l.easing Transactions involving Special Purpose Entities'.

"See D.J. Ragone III, 'Current Accounting Projects', 2000 Conference on SEC Developmints (4 December 2000). 
so it stays just within the bounds set by a rule $\mathrm{e}^{52}$ - clearly is widespread. But these rule-based aggressive treatments, which tend to involve structured finance, leases, and (until recently) pooled mergers, do not show up in large numbers on the list of recent restatements. The reason is that the rules make the treatments GAAP-compliant, even as many observers disapprove of the treatments.

The audit failures and restatements follow less from regulatory arbitrage than from strategic noncompliance - action under an interpretation of the law in conflict with the stated interpretation of the regulator. ${ }^{53}$ Neither rules nor standards prevent such conduct, and, as between the two, rules have the advantage in deterring it. Meanwhile, in every case of a restatement, GAAP by definition has proved adequate to the job of identifying the misstatement and providing corrective instructions. Under this analysis, the drafters of SOA were right in thinking that the absence of principles has contributed to the crisis but wrong in diagnosing the problem as legislative. This is not for the most part a problem concerning the relative merits of rules and principles in standard setting. It is instead a problem of professional practice in a regulatory system made up of both. It is the auditors who need to get back to principles, taking seriously principles already governing the reporting system.

\section{THE DEMAND FOR RULES}

We have seen that US GAAP literally follows from general principles. Yet it has become more and more rules-based as articulated over time. This is not because its general principles no longer motivate particular GAAP standards, but because US accounting's constituents constantly and effectively register demands for tailored treatments. The propensity toward rules follows from a supply and demand dynamic between the standard-setter, FASB, the audit firms, and their management clients.

The demand for rules follows from auditing clients' constant desire for exception from rules. When an accounting principle articulates a treatment category and a set of reporting companies dislike the way the treatment applies to them, they (and their auditors) lobby for an exception. One means to the end of permitted deviation from the mandated treatment is a 'scope exception' - a rule that rule excludes stated transactions or items. ${ }^{54}$ GAAP's complex derivative rules provide a good example, with their nine exceptions to the definition of derivative, several of which came into the rules solely for the purpose of

52 See T.F. Malloy, 'Regulation and the Compliance Norm', UCLA Law School working paper, 2003 (on file with author).

${ }^{53}$ Ibid.

Schipper, loc. cit. n. 17, pp. 66-67. 
reducing preparation costs. ${ }^{5.5}$ Alternatively, constituents request and attain 'treatment exceptions' - special rules for defined items or industry practices. Rules facilitating income smoothing provide a prominent example. ${ }^{56}$ Having won their rule-based exceptions, the constituents then request detailed instructions respecting implementation. ${ }^{57}$ FASB responds, and GAAP becomes still more complex.

\subsection{FASB: the responsive standard setter}

GAAP has very close formative ties to the profession that applies it, ties closer even than those between US legislatures and judges and the legal professionals who advise corporate clients. Government mandates dictate much of the advice lawyers give to clients. But the government, although heavily populated with lawyers, operates at arm's length from the legal profession. Accounting, in contrast, operates like a guild both at the legislative and at the professional level. Auditors apply law generated within their own profession, operating at closer quarters with the pertinent lawmaking institutions than do lawyers.

The governance structure of FASB demonstrates this proximity. At first glance it appears designed to prevent the large auditing firms from dominating the body that makes GAAP. Public accountants may fill no more than three of FASB's seven seats, with the remaining four seats being taken by two corporate executives, one financial analyst, and one academic. ${ }^{5 \kappa}$ On further consideration, however, the four to three split does not provide a credible guarantee against special interest influence. Auditors and corporate audit clients will have a community of interest on most hot button standard setting issues. FASB, by coupling three auditors with two corporate executives, assures that this community of interest has a five-to-two voting advantage. FASB also is a very small shop, with a staff of only forty-five. For funding, it has historically relied on the charitable support of the large audit firms, along with a trickle of revenues from publication sales. ${ }^{50}$ Add all of this up, and the structure does not guarantee robust institutional independence for GAAP's standard setter.

With this incentive problem in mind, let us revisit FASB s withdrawal of its two decades old project looking toward a substance-over-form approach to

Is. Ibid. p. 66.

5t" Ibid.

${ }^{37}$ Ibid, p. 67.

5s Herwitz \& Barrett, op. cit. n. 19, pp 154-156.

5"I Ibid., p. 54. Meanwhile, the Emerging Issues Task Force, which since 1984 has had the job of pronouncing on cutting-edge requests for advice on appropriate treatments, is a group populated almost entirely of representatives of the large firms. Ibid. p. 157. 
defining control and imposing consolidation. ${ }^{60}$ Why did FASB give up? It seems unlikely that the decision followed from a jurisprudential commitment to rules-based accounting. More likely FASB abandoned the project because it expected a shift to a standard to trigger vociferous opposition from reporting companies and the large audit firms because it would have had a restraining effect on the structured finance. Securitization is a billion dollar industry. Auditing firms participate as consultants. Reporting companies securitize their assets to enhance their bottom lines. Market intermediaries draw enormous revenues from making the deals. To the extent that a new consolidation regime would have chilled deals by changing accounting treatments, all of these actors would have gone straight to the barricades to protect the status quo. FASB, after years of being greeted with threats from lobbyists and attack dog congressmen whenever it tried to improve anything, was entitled to be a little gun shy in the face of strong demand for the status quo respecting consolidation.

It should be noted that corporate managers do not have the power simply to dictate GAAP's terms. GAAP rule-makings are much contested, despite FASB's structural weakness and management's capture of the auditor interest. Indeed, FASB has conducted itself with admirable independence in recent years, taking positions opposed to those of management and the audit profession on key issues like the treatment good will arising in mergers and management stock options." But FASB's structural weakness does bear on the rules versus principles choice in day-to-day standard setting. When empowered constituents present FASB with a standard-setting problem or pose a question about a proposed standard, in either case asking for a solution in the form of a scope or treatment exception, they often get a sympathetic hearing.

US GAAP accordingly presents a cognisable capture problem. GAAP in many respects results from an internal conversation, with no institutional mechanism assuring that the public interest trumps the interests of audit firms and their clients in its promulgation. Asymmetries of information and methodological wherewithal aggravate the problem. GAAP is a body of law structurally shielded from outside inspection. Monitoring GAAP is difficult - to know what is going on respecting substantive issues in accounting is to be a member of the guild in the first place.

Solidarity within the accounting profession aggravates the problem. This profession closes ranks when a major conflict breaks out between it and the rest of the economy. Among the multitude of talking heads from the business world that provided the US media with its sound bites during recent corporate crises, none were partners from the large auditing firms. Even as the rough and tumble

\footnotetext{
60) Supra n. 40 and accompanying text.

${ }^{61}$ A. Levitt, Take On the Street: What Wall Street and Corporate America Don't Want You to Know, What You Can Do to Fight Back (New York: Random House 2002) pp. 106-115.
} 
world of public policy discussion suddenly occupied itself with GAAP and the audit profession, the audit firms stayed silent..$^{62}$ The silence hardly stemmed from disinterest. It instead served to preserve information asymmetry - the less said about audit practice outside the profession the better. Industry concentration augments accounting's professional solidarity. There remain only four firms left with the wherewithal to conduct audits of large capitalization companies. In a universe of four organizations, discipline is easily maintained.

The legal profession in the US, with all its faults, displays no comparable solidarity. For every lawyer who closes ranks with a corporate client, there is another lawyer looking to bring suit against that first lawyer's client, or, alternatively, to get the legislature to authorize a lawsuit. When the corporation's lawyer goes to Capitol Hill to get the client protective legislation, the trial lawyers also are there, working the other side. When lawyers advocate for their clients in public, they are understood to be acting in a special role. Any representations they make on clients' behalf concerning the state of the law are greeted with scepticism. Indeed, critique usually is assured, for a second lawyer will be charged with articulating the opposing view.

Accountants operate differently as a profession; even as they have come more and more resemble lawyers in playing an advocacy role for their clients. Where with lawyers the advocacy appears in briefs and memoranda of law, with accounting the advocacy merges into the numbers reported on the clients' certified financials. Readers of financial reports have not been on notice to bring scepticism to bear, at least until very recently. And those who do proceed cautiously get only indirect means within the reports' four corners with which to sort numbers influenced by advocacy from harder numbers uninfluenced by management's agenda. This does not go to say that financial reports always are taken at face value. In theory, Wall Street's financial analysts play the critical function. Unfortunately, in recent practice they too have lacked the incentive to criticize. ${ }^{6.3}$ Nor can we assume that a vigorous critique will emanate from within the accounting profession, for it has no segment with a financial stake in articulating adversary positions. The entire burden of critique and correction has devolved on FASB, the SEC accounting office, ${ }^{\text {et }}$ and a handful of academics.

\footnotetext{
nz We must put to one side Arthur Andersen's Joe Berardino, who publicly and unsuccessfully acted out the role of the CEO trying to quell an organizational conflagration.

The incentive problem stems from underwriting and other rent streams flowing from the issuers of financial reports to the employers of analysts. It is not clear that the problem admits of an easy solution. Absent that corrupting rent flow, it is not clear that resources exist to support an adequate llow of critical analysis. Restating the point, reform implies a new pricing structure for the audit.

at The SEC had the power to impose accounting rules prior to SOA. See 15 U.S.C. Ss. 77(a), $78 m(b)(1)$ (1994). The SEC exercises its power only rarely, preferring to leave the job to FASB. acting under the threat of intervention should the SEC's preferences not be satisfied. Herwitz \& Barrett, op. cit. n. 19. p. 146.
} 


\subsection{Audit Firm Demands}

Auditors are inclined toward cooperation with their clients and will tend to support their clients' reporting objectives. Competition for consulting business aggravates the inclination. Auditors also are disinclined to say no to their clients. It follows that before so doing they will seek the backing of a precise negative instruction in GAAP. The rule denudes the negative response to the client of any suggestion that the nay-saying stems from the auditor's own professional judgment. The external authority takes the blame. Under the prevailing relational pattern, audit clients balk at negative auditor demands absent a precise written justification: 'Show me where it says I can't do this. ${ }^{65}$ This professional dynamic generates a high demand for rules.

The profession's fear of enforcement entanglement strengthens the preference. With an open-ended principle, both the preparer and the auditor make a judgment respecting a law to fact application. Risk averse actors in this posture will be wary of second-guessing by regulatory authorities. ${ }^{\text {th }}$ They fear that the good faith they bring to the principle's application will be unverifiable ex post. Principles, then, make it hard to minimize enforcement risk.

It follows that a high demand for rules could persist even in the wake of an across the board ban on nonaudit consulting. Recall that the 'check-the-box' allegation against rules-based GAAP can be restated in positive terms: Rules enhance verifiability, causing a decrease in differences in measurement and making non-compliance more evident. Now assume, as some assert, ${ }^{17}$ that the audit firms engage in intense price competition (even as the number of firms equipped to audit large capitalization companies has decreased to four and quite apart from competition for consulting rents). Such price competition could come at the cost of audit quality. To see why, hypothesize the incentives of an audit partner under pricing pressure. Under Generally Accepted Auditing Standards, the audit process begins with an appraisal of the risk of compliance failure at the client. The auditor's professional judgment concerning the scope of the testing to be conducted in the course of the audit follows from this risk appraisal. ${ }^{\text {i. }}$ The scope of the testing in turn impacts on the audit fee - as the risk increases, more tests are needed, more time must be spent, and the fee rises. Rules recommend themselves over principles in a hard cash sense at this point in the scenario. Check-the-box verifiability gets the job done more quickly and

".5 SEC Report, op. cit. n. 13, s. III.I.

See ibid., s. I.C.

67. See S. Sunder, 'Rethinking the Structure of Accounting and Auditing', Yale ICF Working Paper No. 03-17 (29 May 2003) (available at <http://papers.ssrn.com/sol3/ papers.cfm?abstract_id=413581 $>$ ) (last visited 26 January 2004).

${ }^{\text {ax }}$ Herwitz \& Barrett, op cit. n. 19, pp. 200-203. 
predictably, making it easier to state a price in advance and lock in a profit on the engagement. Under a regime of principles, the preparer will have made fact sensitive applications of the standards, necessitating a more labour-intensive audit. With principles, unexpected, time-consuming problems also are more likely to arise. In sum, professional price competition, to the extent it exists, also fuels the demand for rules.

\subsection{The legal profession compared}

US auditors, in demanding rules from their standard setter, track the actions of US lawyers; and US GAAP, in evolving away from broad principles toward rules, tracks the evolution of US business law as a whole. Before telling their clients that a course of action is prohibited, lawyers also seek an explicit statutory bar or a case on all fours. Business law and lawyers no longer subscribe to the legal realists' view that fact specilic adjudication under principles makes law more responsive. ${ }^{(0)}$ As an example, compare the old Uniform Partnership Act, ${ }^{70}$ drafted early in the twentieth century, with a Revised Uniform Partnership Act, ${ }^{71}$ drafted at the end of the century. The former is a collection of short, general statements. The latter is a labyrinthine affair that reads like an attempt to answer every question that ever arose in this history of partnership governance. The evolution of the Uniform Commercial Code (UCC) and the cases thereunder over the last three decades has worked similarly. New legislative drafts of the UCC add layers of complications. Today's drafters no longer leave it to later case law to fill in the details. Instead they pursue the impossible dream of creating complete sets of instructions, just like the accountants. ${ }^{72}$ Meanwhile, courts applying the UCC have abandoned general ideas like liberal construction ${ }^{73}$ and good faith. ${ }^{74}$

Many reasons for business law's movement to rules can be suggested. Confidence in judicial decision-making has declined even as the expense of litigating questions of interpretation has risen. In commercial law contexts the scope of jury control over mixed law and fact questions expanded materially over the

(") See W.W. Bratton, 'Berle and Means Reconsidered at the Century's Turn', 26 J.Corp.L. (2001) pp. 737. 746.

71. Uniform Partnership Act, 6 ULA 275 (1914).

7 Revised Uniform Partnership Act, 6 ULA 1 (1997).

72 Compare the original UCC Art. 9 and the revised Art. 9 on the perfection and priorities of security interests, See UCC ss. 9-301-9-318 3A ULA 859-1037, 3B ULA 33-386 (1972); UCC ss. 9-301-9-342, 3 ULA 154-301 (2000).

${ }^{73}$ See G.E. Maggs, 'Karl Llewellyn's Fading Imprint on the Jurisprudence of the Uniform Commercial Code', 71 U. Colo. L. Rev. (2000) p. 541.

${ }_{74}$ W.W. Bratton, 'Venture Capital on the Downside: Preferred Stock and Corporate Control', 100 Mich. L. Rev. (2002) pp. 891, 933-934. 
latter part of the twentieth century, destabilizing the expectations of business people. There also circulates a general notion that specific instructions import certainty that enhances economic welfare. Finally, lawyers, like auditors, turn to rules because they want to reduce risk both for themselves and their clients. A rule imports a safe harbour and control of future events where a standard does not.

To sum up, GAAP and business law have moved to rules simultaneously. Auditors, lawyers, and clients alike demand clear instructions, putting the burden of clarity on the lawmaker. They thereby relieve themselves of the burden of making judgments under uncertainty. Such judgments take time, cost money, and disrupt client relations. This is not a healthy development. But the fault lies neither in the proliferating rulebooks nor their drafters. The fault occurs at the point of demand: Drafters will continue to generate rulebooks until the demand ceases. Actors in practice will perceive the rulebooks to be inflexible and burdensome only with the cessation of the forces generating the demand.

\section{RELATIVE MERITS OF RULES AND PRINCIPLES: IDEAL CONDITIONS AND INCENTIVE INCOMPATIBILITY}

For the sake of argument, let us assume that the auditor-client demand for greater rule specificity ceases, freeing us to interrogate in a neutral policy space the question whether GAAP should be articulated in rules or principles. The result will depend on the inquiry's further assumptions. If an ideal professional environment is hypothesized, in which the auditor works unconstrained by pressures of time, price, and reputation, a strong case can be stated for a principles-based regime. But a plausible case can be stated for rules even under such ideal conditions. The case for rules strengthens materially in an imperfect institutional framework, such as that prevailing respecting the audit function in the US.

\subsection{Cost savings and transparency}

Rules-based accounting entails cost savings and enhances transparency. The cost savings follow from the nature of the subject matter. Accounting standards govern homogenous, recurrent situations where the actors need ex ante instructions and have incentives to invest in compliance. ${ }^{75}$ Such conditions tend to justify a rules-based approach. An across-the-board shift to principles would

${ }^{75}$ See L. Kaplow, 'Rules versus Standards: An Economic Analysis', 42 Duke L.J. (1992) pp. $557,570-77$. 
make sense only if the costs of constant revision of the rules to keep up with unintended applications due to faulty drafting and regulatory arbitrage outweighed the benefits of advance specification. GAAP does not appear to lie anywhere near that level of dysfunction. On this analysis, the indicated course of reform is incremental change. The standard setter monitors the rules' operation looking to periodic amendment, adjusting categories so that reporting results follow from the rules' operative principles. ${ }^{76}$

Transparency imports a second justification for rules. Recall that rule compliance is more easily verified than principle compliance. ${ }^{77}$ It follows that rules decrease the risk of audit failure even as they import inflexibility.

Rules enhance transparency for users of financial statements as well as for auditors. To see why, revisit the legal realists' case for principles over rules in respect of private law adjudication. That case presupposes that the law to fact application is explained and published in a judicial opinion. The reported cases give the practitioner an expanding body of fact sensitive applications, ever better articulating the standard's meaning. Over time, the accumulated case law offers the practitioners a level of certainty not dissimilar to that of a rulebook, even as the principle's flexibility is retained. Meanwhile, the cases (and thus the substance of the legal regime) are open for public inspection.

The ongoing rules-based articulation of GAAP by FASB and other public bodies works similarly. ${ }^{7 x}$ But the application of open-ended accounting principles by reporting firms and auditors does not. Financial statements and footnotes are very summary documents. Decision making about treatments goes on in a black box, evolving as a matter of practice amongst insiders. ${ }^{79}$ There is no comparable moment of transparency respecting the law to fact application. This diminishes the chance for outside evaluation. These law-tofact decisions, meanwhile, are not made by judges empowered by the state. They come from the preparers - the regulated actors themselves - acting with an input of the auditor's professional review. And a professional, even one historically conceived to be in an adversary posture to its client, is in a materially different position from a judge. Adjudicatory authority imports absolute

7h. The rule might be overinclusive; that is, it might bring inappropriate transactions into a given zone of treatment. A rule also might be underinclusive; that is, it might allow a transaction that should be included in a treatment category to be structured so as not to be included. See C.R. Sunstein, 'Problems With Rules', 83 Cal. L. Rev. (1995) pp. 953, 995.

77 See text accompanying $\mathrm{n} .37$ supra.

${ }^{7 \times}$ According to FASB, any bias toward rules in contemporary GAAP stems from exactly this sort of law-to-fact development process, as rules are rewritten to take into account different transactional facts and interpretive opinions accumulate. FASB, Principles Approach, op. cit. n. 20 , pp. 3-4.

The three per cent rule applied to SPEs provides a good example, see supra text accompanying $\mathrm{n} .50$. 
power to say no. The outside professional can only suggest no, on pain of giving up the client.

When confronting substandard financials, today's auditors are disinclined even to threaten to walk, much less actually to forego the rent flowing from the audit engagement. A serious incentive problem results, a problem that makes a move to flexible, open-ended principles ill advised at this time.

\subsection{Flexibility and professional judgment}

The case for principles-based accounting arises in large measure from the description of the perverse effects of rules. The principles case admits the force of the rules case but asserts that once rules come to dominate the accounting regime, cumulative perverse effects cause the disadvantages of rules to outweigh the advantages. The more detailed the set of exceptions, the greater the chance that essentially similar transactions receive different accounting treatments. Scope and treatment exceptions build inconsistencies into the standards, sacrificing the integrity of the underlying principles. Strategic behaviour results, as preparers seek to exploit the inconsistencies, designing compliant transactions that subvert the principles the rules supposedly effectuate. Meanwhile, the proliferating exceptions fuel additional demand for explication from the standard setter. The responsive standard setter finds itself attempting to articulate a treatment for every conceivable scenario. But the attempt always fails, for the goal of a perfect, exhaustive rulebook is unattainable. $^{80}$

The case for principles at this point reverses the case for rules. Since the standard setter cannot identify all pertinent business situations ex ante, it is not clear why exhaustive instructions should be held out as a goal in the first place, given that micro-level standard setting always results in inconsistencies. The only party with all information respecting a given transaction is the reporting company itself. It follows that the company's preparer, operating in good faith, is more likely to derive an appropriate treatment when applying a principle than is a rulemaking standard setter acting ex ante. With principles, companyspecific knowledge and the regulatory framework interact flexibly and the regulation's purpose is more likely to be effectuated. ${ }^{8}$

Thus described, principles-based accounting not only permits but also requires exercises of professional judgment by auditors and actors at reporting companies. ${ }^{82}$ Sir David Tweedie, chairman of the IASB, stressed the importance

\footnotetext{
SEC Report, loc. cit. n. 13, s.I.C.

${ }^{* 1}$ Ibid., s. I.D.

${ }^{* 2}$ Schipper, loc. cit. n. 17, p. 61.
} 
of professional judgment in a principles based system in his 2002 Congressional testimony:

'We favour an approach that requires the company and its auditor to take a step back and consider whether the accounting suggested is consistent with the underlying principle. This is not a soft option. Our approach requires both companies and their auditors to exercise professional judgment in the public interest. Our approach requires a strong commitment from preparers to financial statements that provide a faithful representation of all transactions and a strong commitment from auditors to resist client pressures. It will not work without these commitments... ${ }^{, 3}$

Having heard the case for principles, we must return to the auditor-client relationship to inquire into the expected quality of prolissional judgments. If recent history is predictive, the prognosis is not good. Even as atuditors have been disempowered with respect to their clients, so the clicnts have been guided by short-term solicitude for their stock prices rather than fidelity to accounting principles. Proponents of principles seem to believe that reformulating rules into standards by itself solves these problems. But the belief is unfounded. The recent history of audit failure has been no respecter of principles. It will take more than a new approach to standard setting bring incentive compatibility to this compliance environment.

The SEC displays sensitivity to this problem in its SOA report on principlesbased accounting. The report's definition of an ideal principles-based standard makes an interesting comparison with Sir David Tweedie's approach:

'...[T]he optimal principles-based accounting standard involves a concise statement of substantive accounting principles where the accounting objective has been incorporated as an integral part of the standard and where few, if any, exceptions or internal inconsistencies are included in the standard. Further, such a standard should provide an appropriate amount of implementation guidance given the nature of the class of transactions or events and should be devoid of bright-line tests. Finally, such a standard should be consistent with, and derive from, a coherent conceptual framework of financial reporting. ${ }^{, 4}$

Where Tweedie lays the responsibility for law to fact determinations squarely on the regulated actors, the SEC hesitates. It takes a step back from the case for principles to endorse constituent demand for specificity. It then shifts the burden back to the standard setter to provide 'an appropriate amount of

\footnotetext{
.3. Testimony of Sir David Tweedie Before the Senate Committee on Banking, Housing and Urban Affairs (14 February 2002).

SEC Report, op. cit. n. 13, s. I.C.
} 
implementation guidance.' Bald statements of principles, says the SEC, provide users insufficient structure in which to frame their professional judgment. The 'principles' need to be 'defined specifically.' The SEC calls this an 'objectives-oriented' approach to principles-based standard setting. As an exemplar, it holds out FASB's recent revision of the standard for mergers. ${ }^{85}$

The regime envisaged by the SEC appears to hold out the benefit of a decrease in the level of reporting detail. At the same time, comparability of treatment across different issuers would be enhanced. But the decrease in complexity implies a concomitant loss of transparency, since commonality of treatment obscures particulars in the economics of differing underlying transactions. ${ }^{86}$ The SEC sees these as matters to be traded off by the standard setter: "[T]he task of the standard setter [is] to determine the trade offs among relevance, reliability, and comparability (...) in (...) an effort to find the "sweet spot" "87. Two additional SEC instructions to the standard setter stand out: (1) economic substance should drive the development and scope of the standards, ${ }^{88}$ and (2) no scope and treatment exceptions should be conceded. ${ }^{89}$

A question must be asked about the SEC's vision of accounting standards. How does the regime simultaneously articulate precise instructions and eschew all exceptions from its categories? So doing would amount to a considerable achievement. The drawing of lines is intrinsic to regulation. Line-drawing is what case law under principles is supposed to do. It is not at all clear that financial reporting principles differ from any other body of regulations in this regard. So, to the extent the SEC looks toward a new regime in which all standards mesh like the parts of a well-running machine, it is likely to be disappointed. Such perfect engineering is no more likely here than in any other regulatory context. ${ }^{90}$ The search for 'sweet spots' is better consigned to sporting and other physical activities.

The SEC, in its search for a regime of broadly stated standards that incorporate no exceptions, might be better off abandoning the rubric of principlesbased accounting. The system envisioned more accurately would be characterized as a one of tough, general rules. ${ }^{91}$ Such a regime holds out advantages. For example, it presumably would prohibit whole classes of aggressive treatments tolerated in recent years, particularly those facilitating earnings management. But if this is the SEC's intent, a question arises: In the present political and

\$s. Ibid, s. I.C, I.E.

${ }^{86}$ The comments in the text draw on FASB, Principles Approach, op. cit. n. 20, p. 7.

${ }^{87}$ Ibid.

${ }^{88}$ Ibid.

${ }^{89}$ Ibid, s. IV.D.

*) See FASB, Principles Approach, op. cit. n. 20, p 6.

"FASB's Proposal respecting Principles in effect warns audit firms and issuers of this when it points out that principles will mean more volatility in reported earnings figures. Ibid, pp. 7-8. 
institutional context how likely is it that reporting companies, their auditors, and their friends in Washington would permit FASB to use the rubric of principles-based accounting to usher in a new era of strict treatments? Even as the $\mathrm{PCAOB}$ takes steps to regulate the audit profession, the answer must be, very unlikely.

As a practical matter, then, the projected move to principles will have to be articulated in the form of general but flexible guidelines - what lawyers call "standards."

Choices of treatment will have to be made and the quality of preparer and auditor judgments will matter. The SEC warns that principles-based accounting implicates a more expensive, time-consuming audit process. The SEC anticipates that, in order to review preparer judgments, audit firms will have to hire expensive personnel with expertise in complex transactions. It also anticipates that active audit committee oversight and other strong enforcement agents will be required if the system is to work. Finally, it advises auditors and preparers to generate extensive paper records respecting treatment decisions so as to position themselves to defend their good faith."

In effect the SEC asks users of financial statements to trust in the effectiveness of the PCAOB to create a compliance environment very different from the one prevailing - a wonderful new world of accounting. The question is not whether the regime it projects would be an improvement on the status quo; it would be. The question is whether the ideal world thus projected is fieasible in practice without unintended effects in the form of poor professional judgments. It is too soon in the US reform process for an affirmative answer.

\section{CONCLUSION}

US GAAP, even as it has moved to rules, continues to contain many principles and holds out many choices of treatment. Independent auditors are supposed to make reference to the principles in filling in the inevitable gaps in the rules and in answering questions of interpretation under the rules. Such law to fact applications should with some frequency have been leading auditors to say no to aggressive treatments chosen by their clients. But such nay saying has not been the practice. Application of principles in the manner contemplated requires exercises of judgment, exercises that captured auditors are disabled from

"2. Dennedy, 'Form and Substance in Private Law Adjudication', 89 Harv. L. Rev. (1976) p. 1685. offers the classic description of standards in American jurisprudence. America's principles-based accounting advocates would be well advised to read it.

"SEC Report, op. cit. n. 13, s. III.I. 
making. Principles-based accounting only works when the actor applying it takes responsibility for its judgments.

The US accounting crisis stems less from the form of GAAP standards, whether rules- or principles-based, than from their application to fact and enforcement. The system's problems arise out of the professional relation between auditors and clients. It follows that SOA correctly prioritises professional regulation in the form of the new PCAOB. It is less clear that rules-based GAAP should be a present law reform target. Until the enforcement mechanism works more reliably - and the PCAOB is only beginning to task of correction a move to principles-based accounting could aggravate the crisis of confidence. 